\title{
Classroom interaction and its potential for literacy learning
}

\author{
Catarina Schmidt ${ }^{1 \star}$, and Marianne Skoog ${ }^{2}$ \\ ${ }^{1}$ University of Gothenburg; ${ }^{2}$ Örebro University, Sweden
}

\begin{abstract}
This article elaborates on classroom interaction in relation to literacy learning across the curriculum. Drawing on a study in two grade six classrooms in Sweden, we report on identified possibilities of interaction during 12 lessons in the two subject areas of Law and Rights and World Religions. The analysis focuses on the register of repertoires for interaction through organisation and teaching talk and, to some extent, learning talk (Alexander, 2008). These repertoires, and the possibilities they create, are related to Cummins' (2001) framework. The results elucidate the important role interaction plays for students' learning of literacy through subject content and vice versa. Drawing on the results, we argue it is necessary to consider the students to be participants with resources, who can increase their possibilities of taking active part in both the initial, intermediate and final phases of learning in various subject areas if interaction is more present. In this way the students can get access to classroom practices, drawing on various subject content, that more strongly support them to develop sustainable abilities of literacies and specific subject knowledge. The latter is necessary for the learning of all subjects across the curriculum, but also for future commitment within society and citizenship.
\end{abstract}

Keywords: Classroom interaction; literacy learning; across the curriculum and subject content

Received: May 2016; Accepted: November 2016; Published: March 2017

\section{Introduction}

Within mainstream schools in Sweden, subject-based literacy learning and literacybased subject learning is often, but not always, seen as a dualistic goal. In this article we draw on a comprehensive view of literacy teaching and learning, meaning that we hold an integrated perspective on literacy education and the learning of subjects across the curriculum. Such a perspective stresses the need for students to learn, not only the subject content, but also subject-specific ways of understanding, talking, reading and writing (e.g. Skaftun, 2015, p. 1). At focus in this sub-study ${ }^{1}$ are the

*Correspondence to: Catarina Schmidt, Göteborgs Universitet, Box 300, 40530 Göteborg, Sweden. Email: catarina.schmidt@gu.se

${ }^{1}$ The sub-study is part of the research project Understanding Curriculum Reforms - A TheoryOriented Evaluation of the Swedish Curriculum Reform Lgr 11. The Swedish Research Council finances the project. For more information, see: web link. 


\section{Schmidt and M. Skoog}

observed organisational possibilities of classroom interaction together with teaching talk and learning talk in two Swedish classrooms in grade six during the subject areas Law and Rights and World Religions. By teaching talk and learning talk we refer to the talk that take place in the classrooms between teachers and students and among students themselves. When teaching the specific subject content, both teachers used hours from the subjects Swedish and Swedish as a Second Language.

Drawing on the theoretical perspectives presented in the following, we consider interactional processes to be crucial for literacy learning across the curriculum. We view repertoires of interaction as being situated in social classroom practices and, above all, to have consequences for students' learning of various subjects' content and their development of literacy.

In the Swedish national curriculum, $\operatorname{Lgr11}$, fundamental values and guidelines for education are followed by the syllabi, where the aim is presented together with core content for each subject in grades 1-3, 4-6 and 7-9 (National Agency of Education, 2016). Finally, knowledge requirements are formulated in relation to grades $\mathrm{A}, \mathrm{C}$ and $\mathrm{E}$ in terms of what a student is able to do on different levels of intensity, in a basically functional way, an appropriate way, or an appropriate and effective way (ibid.). According to part one in Lgr11, education should "promote the pupils' further learning and acquisition of knowledge based on the pupils' backgrounds, earlier experience, language and knowledge" (ibid. p. 10). Through rich opportunities of discussing, reading and writing, the students "should be able to develop their ability to communicate and thus enhance confidence in their own language abilities" (ibid, p. 11).

According to the syllabus of religion, which is part of $\operatorname{Lgr} 11$, teaching should give the students opportunities to develop their ability to "reflect over life issues and their own and other's identity" (ibid. p. 176). Turning to the subject of civics, it is stated that teaching should give students "opportunity based on their personal experiences and current events, to express and consider their views in relation to others who hold different views" (ibid. p. 189). These latter and earlier quotations from Lgr11 altogether highlight interaction, in terms of discussions and open dialogue, as desirable within education. When students express themselves orally and when they communicate through script in various genres and media, they are at the same time practicing abilities that are interwoven with and required in the subjects of religion and civics, and not the least in Swedish and Swedish as a Second Language. According to the aim of the two last subjects, it is stated that education should give students opportunities to develop their ability to "express themselves and communicate in speech and writing", "adapt language to different purposes, recipients and contexts" and to "search for information from different sources, and evaluate these" (ibid, p. 211-212, 227-228).

In this article we focus on the repertoires of interaction through organisation and teaching talk in the two classroom settings. The main part of the article involves presentation of the observed interactions, drawing on analysed video recordings and transcripts of interviews. Using this analysis we go on to discuss the identified possibilities of interaction in relation to the students' literacy learning across the curriculum. 


\section{Study and aim}

The sub-study reported on in this article draws on a one year long study in two grade six classrooms in two different schools and municipalities in Sweden. The two classrooms are characterized as being linguistically rich. At least one quarter of the students are multilingual in the sense that they speak another language at home or have another lingual background, than Swedish. The focus of this sub-study is to observe and identify possibilities of teaching talk, and to some extent learning talk, in the two classrooms during the subject areas Law and Rights and World Religions respectively. The aim is to investigate and elaborate on the role that interaction plays for literacy learning through subject content.

We ask:

- What possibilities of organised interaction and interaction through teacher talk are identified and what characterizes the register of these two repertoires?

- What effect does the register of these two repertoires have on the students' learning talk and their literacy learning through the content of these subject areas respectively?

Further, our aim is to problematize and discuss the result in light of the national curriculum of Lgr11, and in relation to the framework of Jim Cummins (2001).

\section{Theoretical standpoints}

The use of language through interaction has a crucial role for thinking and learning, which includes both the use of everyday language and more specific subject language (Vygotsky, 1978). To be able to develop thinking and learning, students need to start from their own experiences and from what they are capable of right now. At the same time, students are depending on interaction for using language to cognitively process, sort and understand concepts and develop further knowledge in relation to various content. We consider this to be dialogic teaching (Bakthin, 1986) in line with sociocultural theory (e.g. Lave \& Wenger, 1991; Säljö, 2000). We believe there is a need for a better understanding of how interaction is organised and why, and above all, what the accessible register of repertoires of interaction means for different students.

\section{The role of interaction, language and literacy}

Through various subjects students meet a wide range of texts, which they need to use functionally, understand and make meaning from. Hence, students are relying on their own sustainable literacy abilities and an education that supports the development of such. Alan Luke and Peter Freebody (1999) have developed the Four Resources Model with the ambition to move away from what they claimed to be a too simplistic view of literacy. They describe how effectively literacy teaching invites and allows students to take part and interact in practices that support coding, functional use, meaning-making and critical analyses of spoken, visual and written texts. Following this reasoning, Hilary Janks (2010, p. 21) explains reading as "an active process of 


\section{Schmidt and M. Skoog}

bringing one's own knowledge of culture, content, context, text use and text structure into an encounter with those of the writer, in an active process of meaning making".

Within classrooms and their situated practices, students are continuously defining and redefining social situations, mirroring themselves in relation to these as well as through the texts that they are encountering. Identity is used in talk, is part of language use, and hence is part of being "something that is part and parcel of the routines of everyday life, brought off in the fine detail of everyday interaction" (Antaki \& Widdicombe, 1998, p. 1). Since educational settings, in Sweden and elsewhere, are characterized as being linguistically rich, this of course also affects conditions for interaction.

Cummins (2001) has, through decades of research in multilingual schools, developed a framework for successful academic learning. He accentuates how the following aspects are crucial to scaffold students' language and literacy development: focus on meaning, focus on use, and focus on language. Focus on meaning captures the need of making the content comprehensible. In parallel and depending processes, students must also be scaffolded to develop awareness of the forms and uses of language, and further encouraged and supported to draw on the same content for active and meaningful use of language. These three focuses need to be at interplay since they are depending on one another. At the very core of these focuses is the interpersonal space of maximum cognitive engagement and maximum identity investment, which is depending on the interaction between teacher and student. If students sense that their specific cultural and lingual background is not valued or perhaps not viewed as 'good enough', they most probably will develop reluctance in investing their own identities in the classroom. The latter would then mean an obstacle for interaction, language communication and literacy learning.

Cummins' framework stresses the importance of finding out about students' previous knowledge and experiences. If, for example, a student's entry knowledge is considerable, this might mean that the same student will be able to use language and literacy in more advanced ways. Hence, the latter might be one way of not lowering levels of cognition. Oppositely, instruction through the student's strongest language can contribute in important ways of lowering the cognitive barrier for content knowledge. Likewise, it is important to remember that it might take five years or more for multilingual students to achieve the same levels of language acquisition as first language users of the same age (Cummins, 1981; Hakuta, Butler \& Witt, 2000). This highlights the importance of giving all students possibilities of gradually understanding and using more and more complex language as well as mastering more and more cognitive demanding tasks.

\section{Classroom practices as literacy practices}

Through the study of literacy practices cross-culturally and in relation to different languages, modalities and technologies, research within New Literacy Studies has widened and highlighted a pluralistic and heterogeneous concept of literacy (e.g. 
Barton, 1994; Heath, 1983; Street, 1993). Drawing on this research, literacy is therefore more than a set of autonomous skills. Literacy is instead ideological, resulting in that literacy means different things and are valued differently in different social practices, like for example in classrooms (Street, 1993). In line with that, Cummins $(2001$, p. 125) argues that in diverse contexts "where social inequality inevitably exists, these interactions are never neutral". According to him, interactions "either challenge the operation of coercive relations of power in the wider society or they reinforce these power relations". Luke and Freebody (1999), in their turn, emphasize how literacy learning is about engaging in, transforming, and critically analyzing ways of viewing the world represented by the culture you live in. The theory of literacy means that also cultural, gendered, political and institutional aspects might be added to the time and space of students' literacy learning across the curriculum (Brandt \& Clinton, 2002; Cummins, 2001; Luke, 2004; Street, 2003).

According to Alexander (2008), teaching is an act of curriculum transformation, where the curriculum is enacted and broken down into tasks and activities in the classroom. Classroom interactions are linked to national policy via the curriculum and other guidelines. The latter highlights a micro-macro relationship to educational conditions, linking classroom interaction to national education policy via the curriculum and its possible translations (Alexander, 2008; Skaftun, 2015; Vesteraas Danbolt \& Iversen Kulbrandstad, 2012; Wahlström, 2016).

\section{Classroom studies of interaction}

The theory of literacy as a social practice might further shed light on what kind of resources different students bring to classrooms in the forms of earlier experience and knowledge (e.g. Heath, 1983; Schmidt, 2013; Laursen \& Mogensen, 2016). Through ethnographical studies, conditions for interaction and learning in Swedish classrooms have been elucidated (e.g. Ewald, 2007; Schmidt, 2013; Skoog, 2012; Tanner, 2014). Ewald's study illustrates for example the need for dialogue considering the reading and understanding of fiction literature. Skoog's (2012) and Schmidt's (2013) studies highlight how contemporary literacy education across the curriculum has to take into account all the four practices of Luke and Freebody (1999) referred to above. Tanner's (2014) detailed study of classroom practices highlights how students in so-called desk-interaction situations ${ }^{2}$, are expected primarily to solve problems as independently as possible, and to regulate their work in relation to work-instructions and other texts. Altogether these studies (Ewald, 2007; Schmidt, 2013; Skoog, 2012; Tanner, 2014) bring evidence for the need of awareness among teachers considering the value of dialogic teaching and the crucial role that language and interaction has for learning. Another example is a 3-year study among 9-19-year old students in England, where Barwell (2005) elucidates how attention to the written form, in this

\footnotetext{
${ }^{2}$ Desk-interactions refer to situations when students work individually at their desks while the teacher moves around to support and supervise them (Tanner, 2014).
} 


\section{Schmidt and M. Skoog}

case through the subject of mathematics, provides opportunities for language and subject learning.

Ødegaard et al (2015) bring attention to that although teachers use dialogue as their main mode of whole class teaching, this does not necessarily mean that they include explicit subject specific concepts or arrange for students to practice on these in systematic ways. This highlights how education needs to support the transition from everyday to subject-specific language. Likewise, Klette and Ødegaard (2015) elucidate how analyses of student-initiated sequences reveal a pattern of mainly dealing with practical matters and ways of carrying out a certain learning task.

Alexander (2008) and his research colleagues have, through parallel video recordings of classrooms in five countries, explored the relationship between culture, policy, schooling and pedagogy. Through these detailed analyses of classroom interaction and discourse, three repertoires significant for interaction have been identified: the repertoire of organised interaction, the repertoire of teaching talk, and the repertoire of learning talk.

Regarding the repertoire of organisation, the following possibilities were identified: whole class teaching, collective group work (led by the teacher), collaborative group work (led by the students), one-to-one activities (teacher and student), and one-to-one interactions (students working in pairs). These possibilities of organisation vary selfevidently, in terms of length, space and intensity, and also considering the ways they are steered by the teacher and/or the students.

Regarding teaching talk, the following possibilities were identified: rote, which is drilling of facts, recitation, where questions are used to test or stimulate recall of learning targets and, eventually, instruction, where the students are instructed on what and how to procedure (ibid.). The use of closed-end questions is considered to be a well-established feature of classroom interaction (e.g. Sinclair \& Coulthard, 1975; Mehan, 1979). Less frequently possibilities of teaching talk were discussions in the form of the exchange of ideas and shared information and dialogues, defined as "common understanding through structured cumulative questioning and discussion that guide and prompt" (ibid. p. 110).

The repertoire of learning talk constitutes how students themselves talk, and the forms of oral expressions and interaction that they need to use, experience and master (ibid.). The register of this third repertoire altogether means an active use of language and literacy. Observed possibilities of interaction through learning talk were, according to Alexander (2008), narrating, explaining, asking different kinds of questions, analysing and solving problems, among others. Further, learning talk can mean possibilities of imagining, exploring and evaluating ideas, as well as to discuss, argue and negotiate (ibid.). Alexander (2008) stresses how these possibilities of learning talk are related to the abilities of being able to listen, to be receptive to alternative viewpoints, and to think and reflect about what is being heard as well as to give others the time to think. The repertoire of learning talk depends on the repertoire of teaching talk and the possibilities it creates and supports, and both are also relating to and depending on the repertoire of organisation. 


\section{Methodological approaches}

In each class 12 lessons, and in total 24, have been recorded with one video camera in order to capture dimensions of interaction and also to document the use of instructional materials and texts. Initially we spent some time in the classes, but during the actual recording we were not present so as not to affect the classroom interaction. In addition, five individual interviews with the two teachers and five group interviews with 4-6 students from each class were conducted and transcribed literally. The interviews lasted from 20 minutes to one hour and were based on a structured interview and guided with a focus on the teachers' and the students' reflections considering the purpose, forms and content of the recorded lessons and their learning repertoires. During the interviews, parts of the video recordings were shown in order to make retrospective reflections possible from both teachers' and students' perspectives.

At focus in this paper are the two subject areas Law \& Rights and World Religions. A serial of lessons have been video recorded, which in total cover 7 hours of the 24 hours of video recordings. The lessons are placed in different phases of the teaching process, identified as the initial, the intermediate and the final phase of the subject area. At the same time both teachers used more lessons than were recorded, and additionally this paper draws from all the interviews, and the substudy on the whole.

The larger study, and hence the sub-study, has gone through an ethical review by the Swedish Research Council, and has been carried out in accordance with the general requirements for Research Ethics (Vetenskapsrådet, 2011). All participating schools and informants have been given fictitious names in order to protect their identities during and after the finished project. The students as well as their parents have been informed about the aim of the study, and then asked to give their written consent for participation in the study, which they all did.

In analysing our video data, a fine-grained observation scheme, drawing on Alexander's (2008) methodological framework, has been used. The repertoires of organised interaction and teaching talk during lessons have been analysed with the aim of identifying their possibilities for interaction. Though, not being a possibility for interaction, students' individual work has been identified as one way of organising education. The repertoire of learning talk is in this sub-study analysed in relation to the register of the two other repertoires. Our focus is on the ways that the two first repertoires shape and form conditions for learning talk, and literacy learning.

\section{Identified classroom interaction}

In both subject areas, whole class teaching is initially identified as the dominant way of organising classroom interaction together with mainly rote, recitation or instruction within the repertoire of teaching talk. Lessons placed in the initial phase comprise the teachers' introduction of the subject areas and lecturing on basic facts and key concepts within the subject areas. Lessons placed in the intermediate phase 


\section{Schmidt and M. Skoog}

are characterized of individual work, mixed with one-to-one interaction between the teacher and one student at a time. Here teaching talk most frequently comprises of instruction and to some extent discussion. Thus, the transition from the initial phase to the intermediate phase is marked of the students' individual work. Lessons placed in the final phase imply the ending of the subject area, where the students in various ways show what they have learned, in these cases through an oral account or submitting the task to the teacher in order to be assessed, something that is strongly connected to the Pedagogical Plans, presented by the teachers initially. The pedagogical plans draw on Lgr11 and clarify why, what and how to learn.

\section{Initial phase: Law and Rights}

The initial phase of the theme Law and Rights focuses on presenting basic facts and key concepts of the subject area. After having watched a movie about the Swedish history of law nonstop, the teacher asks some repeating and closed-end questions about legislation in Sweden and the Swedish Parliament, among other things. When only some students raise their hands, the teacher expresses with emphasis: "I want to see more hands in the air," and declares that the students are expected to know about this, since this content has also been treated in grade five. Here teaching talk of rote and recitation is identified, where the students give brief answers to closed-end questions. These two forms of teaching talk blend into one another, and this pattern continues when the teacher tells about the duties of the police and prosecutor as well as explaining subject-specific words, drawing on the movie.

The whole class teaching continues with shared reading led by the teacher in an information booklet ${ }^{3}$ about the duties of the Swedish district court. After each read paragraph, where the students take turns in reading aloud, the teacher summarizes and elaborates on the content. Teaching talk of rote and recitation are again identified. The teacher poses questions about content and concepts. For example, the teacher asks: "What does 'prepare a case' mean?" and "Adoption, what is that?" Other subjectspecific words highlighted are lay judge, division of joint property and bankruptcy. Occasionally a student is asked to explain a word, but more often the teacher explains the meaning of the word. For example, the teacher highlights that lay judges "are appointed by the political parties and are supposed to be the public's eyes in the court, so that the court really is neutral and doesn't favor any particular". Sometimes the teacher gives feedback on a student's answer, but more often there is no feedback at all on the students' contributions. This again illustrates how the teacher talk in whole-class interaction is characterized by recitation/rote.

The initial phase of whole class teaching continues with shared writing of a factual text about the course of events in a legal case. While the students pick up their laptops, the teacher writes the following words on the whiteboard: speeding,

\footnotetext{
${ }^{3}$ The booklet is published by the Swedish Courts (see www.domstol.se). Other text sources used are for example: https://polisen.se, https://www.aklagare.se, www.domstol.se, https://www.kriminalvarden.se together with a study visit at the District Court.
} 
15, prison, innocent, the car, fine, criminal, lawyer, 18 and court. A few questions are heard from the students concerning formal aspects of the writing procedure, like "Shall we write that?" and "What is the title?" Thereafter the teacher starts to write one sentence at the time on his laptop, and simultaneously the students write down the same sentence. Now and then the teacher pauses, asking what words from the whiteboard to fit into a certain sentence, and here teacher talk of recitation is again identified. For example the teacher says: "about judging ... where do you get judged, who are the only ones that are allowed to judge someone in Sweden, which of these words would fit in after "to be judged in a ..." Some students raise their hands, a student gets the word and answers "court". While the text emerges, the teacher continues to question the students about the meaning of the words and also further lectures on the actual topic.

The whole class teaching continues and now teaching talk of instruction is identified. The teacher instructs that the learning task is to individually create websites, based on the factual knowledge the students have acquired so far, and on other information sources they find on the Internet. Here the teacher presents the Pedagogic Plan, where two 'knowledge requirements' are specified. The first 'requirement' is taken from the core content and states that teaching in civics should deal with "society's need for legislation, some different laws and their consequences, crime and its consequences on the individual, family and society" (ibid. p. 191). The second, to be found within the aims, states that students should develop ability to "search for information about society from the media, the Internet and other sources and assess its relevance and credibility" (ibid. p. 189).

In short, each student is supposed to create a website, "Law and Rights", with the help of Google sites. The website shall include one main page and ten subpages with clear language of at least one hundred words on every page, and ten internal and external links inserted together with one movie. Altogether this constitutes what and how the students are going to learn.

\section{Initial phase: World Religions}

When starting up the theme, the teacher hands out textbooks of the subject Religion to be used later on, and then writes fudaism, Christianity, Islam, Buddhism and Hinduism on the whiteboard. Thereafter, the teacher presents the pedagogical plan highlighting a range of abilities justifying why the students are going to work with the subject area. These abilities are to be found within the aims of Religion and Swedish/Swedish as a Second Language, such as analysing different religions and how they are affected by circumstances in society, reflect on one's own and others' identity, search for information from different sources and evaluate those. In addition, the pedagogical plan highlights what to learn, and this time the teacher draws on some of the knowledge requirements, again both in Religion and Swedish/Swedish as a Second Language. Here, teaching talk of instruction is identified with the focus on what to learn. Further, key concepts like rituals and holy places, drawn from the content core of the syllabus in religion, are brought forward. The teacher hands out a worksheet with a 


\section{Schmidt and M. Skoog}

column for each religion linked to these and other concepts such as symbols, sacred texts and followers. Altogether this makes up what the students are going to learn.

The identified teaching talk of instruction includes how the students are going to work in terms of what sources to use: the textbook ${ }^{4}$ together with two websites ${ }^{5}$ (one with written and visual factual information and one with collected educational movies). The students are instructed that they will individually search for factual information of one religion each in relation to the key concepts of the worksheet. Eventually they will present their results through a PowerPoint presentation for peers in split groups.

For a while the teacher's own monologist talk about Christianity in terms of its features and symbols is heard, and this is also summarized in paragraphs on the whiteboard. Some comparisons with the other four religions are made. Further, teacher talk of recitation and brief discussions is identified. When the teacher tells about Abraham6, the progenitor of three religions, one student exclaims: "He is unfaithful", and a blur of up to five students' voices are heard. For a brief moment, learning talk of asking questions and of exploring conditions are identified by some of the students. Rapidly though, the dominant possibility of whole class teaching together with blended teaching talk of instruction and recitation is reestablished, and the student's utterance is left hanging in the air. Teaching talk of instruction is again identified about in what ways the students will be assessed, which in this case includes how they work individually on the lessons and how well they eventually present their specific religion in split groups and perform on the final test. The issues of assessment lead to questions from two of the students, identified as brief moments of learning talk, concerning how long it is before there is a test, for how long they will work with this topic, and if they can choose what religion to work with.

The teacher turns back to the worksheet, where the first column of Christianity is already completed. Again the students are instructed on how they will search for facts regarding the in total eight key words and how they later will fill in the other three columns when listening to their peers' presentations. The teacher starts to draw lots and names the students who are to work with Islam. After a while the teacher pauses and says that four students, all girls with headscarves and having Arabic as their first language, will not work with Islam. "Why?" asks another student and continues: "Are they Islamists?" The teacher answers: "They are to learn about another religion as well." After sorting out all the four religions, whole class teaching continues and the class watches a movie about the world religions during twenty minutes nonstop. The movie has quite an advanced level of language and words, like for example: worldview, belief system and monotheism.

\footnotetext{
${ }^{4}$ Textbook (see http://www.nok.se/Laromedel/F-9/Grundskola-4-6/Religionskunskap/PULS-Religion4-6/)

${ }^{5}$ The website so-rummet (see http://www.so-rummet.se) and a local website where educational movies are collected.

${ }^{6}$ According to the Bible, Abraham has two wives, Sara and Hagar, and one child with each of them.
} 
The initial phase continues over the next lesson, where the interaction is organised through whole class teaching. The students are again instructed to search for facts drawing on the key words. "You can take notes in your notepad or on your iPad, and then when you are presenting you will listen to each other and fill in facts on the religions you have not worked with", the teacher explains. Continuous teaching talk of instruction is identified and the students are now obliged to log into a website, where they can find movies about the world religions. The teacher mentions the other optional educational website about the world religions and repeats: "You can write on a PowerPoint if you like, that or on the iPad".

\section{Intermediate and final phases of both themes}

In the intermediate phases of both subject areas, the lessons are organised through individual work, where interaction is made possible through one-to-one teaching between the teacher and one student at the time. In the case of Law and Rights the students are encouraged to help each other, and in both classes they are allowed to sit next to each other or in smaller groups, in- or outside the classroom. Thus, the students are given some opportunities of interaction through learning talk, like sharing ideas and/or solving problems. Still, the dominating way of organising the lessons during the intermediate phases of the two themes is through individual work.

One difference between the two classrooms is that the teacher regarding Law and Rights commonly starts a new lesson by giving collective comments on the students' ongoing work, concerning both the content of their texts and technical aspects of the creation of the websites. When the students are working individually during Law and Rights, it also happens that the teacher calls for all students' attention in order to clarify some question posed by a student, like for example explaining the relationship between internal and external links on a website by illustrating it on the whiteboard. Apart from identified teaching talk of instruction is also to some extent the students' own questions, initiated by them and identified as examples of learning talk.

When starting up the intermediate phase in World Religions, the teacher says: "Now it shall be quiet and possible to work undisturbed" and adds: "You do not have to do the PowerPoint at once". In both classrooms the student's individual work creates a continuum for a serial of lessons over time.

The two subject areas end in different ways. Regarding Law and Rights the students hand in their respective web site to their teacher, and here the process ends. In the theme of World Religions, the students meet in split groups, telling each other about one religion and at the same time filling in factual information about the other religions on the earlier mentioned worksheet. Here possibilities of learning talk such as narrating and explaining are identified.

\section{The register of organised interaction and teacher talk}

Initially and in both classrooms, the register of the repertoires of organised interaction and teacher talk is characterized of whole class teaching through recitation, 


\section{Schmidt and M. Skoog}

rote learning and instruction. The questions used by both teachers are mainly closed-ended. A majority of the students remain silent during the initial whole class teaching. Consequently, the students are not actively exploring and negotiating on the meaning of content, related words and concepts in their own communication. The register of the two repertoires is further characterized of shared reading followed by recitation, and with basic subject content being summarized by the teacher for the students to write down.

Both teachers confirm shared reading as being commonly used during whole class teaching, one of them stating: "We always read together since it benefits so many, there are many concepts that they don't understand". The students reveal at the same time different opinions regarding this. One student claims not to prefer shared reading and states: "If you read yourself you have to be concentrated on what you are doing". Another student says: "I like it when the teacher reads aloud and we follow in the textbook because I feel that I learn". These two examples highlight the fact that students have different needs, and also that all students get access to one level or version of reading, thinking and exploring about the meaning of the content.

The teachers' explanations and monologues during whole class teaching, which sometimes draw on shared reading of a certain textbook, can of course be said to contribute to making the content comprehensible and support the students to develop language and literacy abilities. Both teachers summarize basic subject content verbally or in paragraphs or sentences on the whiteboard/screen in the initial phase. The students give suggestions and eventually the teacher decides the formulation, which the students are to write down. Again, different opinions as well as prerequisites and needs are revealed among the students. One student describes this retrospectively in the following way: "we decide together", adding "you can raise your hand". Another student declares: "I would learn more if the teacher wrote only main points". This particular student wants to make up own versions of conclusions or summaries of factual information and concludes: "It goes more into the head than if I just am to copy".

Considering the start-up of a new subject area, and in relation to whole class teaching, one student says: "When starting with a new area, usually we have a rather long lesson in the beginning, then we are to explore a little". Altogether this reveals a pattern where the individual student is passive in for example shorter pair work, leading to the fact that their own learning talk of imagining, exploring or arguing is not supported, hence impossible to acheive. In other words the transition from everyday language to subject-specific language is not supported (Ødegaard et al (2015). One interpretation of this pattern might be that the teachers seek to prepare and narrow down what, and above all how, the students are going to work on an individual basis.

\section{Individual work as searching for facts}

During the individual work in the intermediate phase of the two themes, interaction is mainly made possible between the teacher and one student at the time. Regarding 
the actual individual work, one student says: "You were to write down about the religion, for example, places for worship, and you should do this presentation".

When asked about how they work with the subject content, the students recurrently describe how they search for facts. However, the students do not describe on what grounds they choose or value information, and how they interpret the different sources that they use, they simply do not seem to have their own words and/or strategies for this. Regarding Law and Rights, the students describe how they, in addition to using the information booklet published by the Swedish Courts, search for information on the Internet, and how they sometimes are guided to a certain website by the teacher. "All of us can get different information", one of them says and continues: "There are many websites with a lot of different facts". In both classes the students are individually searching for information on the Internet, meaning that they, apart from the presented textual resources by the teacher, also search on Google or YouTube. Both teachers confirm the difficulties this presents to students in considering what to choose and how to value, interpret and critically review found information.

When collecting information about a certain religion, some of the students write down information in relation to the eight key concepts and then start to make a PowerPoint presentation, while others start directly with the presentation. The teacher expresses how the key concepts are supposed to "function as a kind of role model of how much to include". Also, the other teacher relates to the use of key concepts as to be useful for creating knowledge and states: "It is very much about creating a knowledge base with concepts and then to be able to use it in some way".

\section{Translations of a national curriculum}

Drawing on the two classroom practices described above, translations of a national curriculum are made visible. Initially, both teachers present pedagogical plans based on Lgr11. The teachers are in this way justifying their own teaching as well as giving reasons for why the students are supposed to learn certain content. The students confirm the latter, saying for example: "We do that all the time, in each subject it is always the curriculum". In various ways the students give accounts of pedagogical plans and other explicit connections being made to Lgr11. Our analysis implies that the teachers are not introducing the new knowledge area in relation to the students' own curiosity, articulated in their own experiences, authentic questions and/or previous knowledge. The latter can also be said to be one, and a very important, translation of Lgr 11, drawing on the fundamental and democratic values of part one. Further, the results reveal how aims and core content are mixed up with knowledge requirements.

It appears that the students through teacher talk hear about 'knowledge requirements' drawing on Lgr11, and that they understand these as crucial. One student expresses that "to raise your grades you should be able to reason and develop everything" and continues to explain the importance of using "as good words and concepts as possible". The translations of $\operatorname{Lgr} 11$ also include the fact that the teachers in a continuum have to assess and grade students' performances. "When you start 


\section{Schmidt and M. Skoog}

planning, you have to start with the knowledge requirements and the core content, but also include the overall goals of the curriculum", one of the teachers tells.

\section{Power relations}

As commonly being the case with young students, and also being a matter of power structures within educational institutions (Cummins, 2001; Street, 2003), loyalty is shown in the participant students' retrospective reflections. The students often repeat what has been communicated by their teachers in the classroom, and are not questioning the offered repertories of interaction and literacy learning.

The theory of literacy as a social practice implicates what kind of resources different students bring to learning environments in the form of earlier experience and knowledge. Speaking about backgrounds in relation to religion clearly highlights the interpersonal space (Cummins, 2001). The teacher retrospectively comments on the importance of elucidating the fact that not all Muslims are terrorist and this in a class where, according to the teacher, about $1 / 5$ of the students are Muslims. At the same time the teacher decides that those students will learn about another religion. The view of how identity is used, talked about and represented through available repertoires of literacy, reveals that interactions are never neutral, something which is elucidated by this example. Further, these students, which all are multilingual, are part of the majority of students being silent. The latter example shows how these particular students are denied possibilities of representing themselves through their potential knowledge of Islam if they would like to.

\section{Comparative conclusions and implications}

Regarding Law and Rights the repertoire of teacher talk through recitation can be said to focus more on making the basic subject content comprehensible and, in that way, prepare the students for their future individual work. Regarding World Religions, the students more quickly start to work individually. During the individual work of Law and Rights, traces of learning talk is observed during and in combination with the teacher's talk of recitation. Oppositely, interaction between the students and possibilities for their own learning talk are made possible when they are telling each other in groups about the religion they are assigned.

Through the initial whole class teaching, where the content is presented and instructions for future work are given, the students will be able to explore, in terms of reading, drawing conclusions and summarizing factual information presented in movies, textbooks and digital resources on the Internet. For this, we argue that the repertoire of learning talk - that is to say, the student's own talk and opportunities for asking, arguing and reasoning in relation to subject content - needs to be better accommodated (Alexander, 2008). The need for learning talk is closely connected to the approaches articulated in Cummins' (2001) framework. Drawing on the analysed results, it is obvious that the register of the two repertoires of organisation and teaching talk can be widened and deepened in terms of a more dialogic teaching 
with possibilities for exchanging ideas as well as for achieving common understanding (Alexander, 2008), but also so that students can invest in their own identities with the maximum of cognitive engagement (Cummins, 2001).

Drawing on the results, it is clear that more active language use is crucial for all students' literacy learning and especially because one quarter of them have another lingual background than only that of Swedish. Active language use combined with learning talk could, for example, mean that students draw conclusions and summarize a certain part of the subject content, and then are given opportunities to compare this with other peers. This would mean to make use of a wider pallet of possibilities in relation to organisation and teaching talk and that it could help students to move from copying to a more functional and critical writing process.

Altogether the translation of Lgr11 in this sub-study reveals a goal-oriented view where the knowledge requirements, being mixed up or not, are understood as being the desirable knowledge. We argue for the importance of a comprehensive view of literacy education, and that apart from the aim, the core content and knowledge requirements also integrate with the democratic values of Lgr11. Drawing on the results, we argue for the necessity of considering the students as participants with resources, and allowing them and encouraging them to increase taking active part in both the initial, intermediate and final phases of different subject areas. In this way the students can get access to classroom practices, drawing on various subjects' content, that more strongly support them to develop sustainable abilities of literacies and specific subject knowledge. The latter is necessary for the learning of all subjects across the curriculum, but also for self-realization, and for future commitment within society and for citizenship.

\section{References}

Alexander, R. (2008). Essays on Pedagogy. London, New York: Routledge.

Antaki, C. \& Widdicombe, S. (1998). Identity as an Achievement and as a Tool. In C. Antaki \& S. Widdicombe (Eds.), Identities in Talk (pp. 1-14). London: Sage Publications.

Bakhtin, M. (1986). Speech Genres and Other Essays. Austin, TX: University of Texas Press.

Barton, D. (1994). Literacy. An Introduction to the Ecology of Written Language. Oxford: Blackwell.

Barwell, R. (2005). Integrating language and content: Issues from the mathematics classroom. Linguistics and Education, 16, 205-218.

Brandt, D. \& Clinton, K. (2002). Limits of the Local: Expanding Perspectives on Literacy as a Social Practice. Fournal of Literacy Research, 34(3), 337-356.

Cummins, J. (2001). Negotiating Identities: Education for Empowerment in a Diverse Society. Second Edition. Los Angeles: California Association for Bilingual Education.

Cummins, J. (1981). Age on arrival and immigrant second language learning in Canada: A reassessment. Applied Linguistics, 1, 132-149.

Ewald, A. (2007). Läskulturer. Lärare, elever och litteraturläsning i grundskolans mellanår. Malmö: Malmö Studies in Educational Sciences No 29.

Freebody, P. \& Luke, A. (1990). Literacies Programs: Debates and Demands in Cultural Context. Prospect: Australian fournal of TESOL, 5(7), 7-16.

Hakuta, K., Butler, Y. G. \& Witt, D. (2000). How long does it take English learners to attain proficiency? Santa Barbara, CA: University of California Linguistic Minority Research Institute.

Heath, B. S. (1983). Ways with words. Language, life and work in communities and classrooms. Cambridge: Cambridge University Press.

Janks, H. (2010). Literacy and Power. New York and London: Routledge. 


\section{Schmidt and M. Skoog}

Klette, K. \& Ødegaard, M. (2015). Instructional Activities and Discourse Features in Science Classrooms: Teachers Talking and Students Listening or ...? In K. Klette, O. Bergem \& A. Roe (Eds.), Teaching and Learning in Lower Secondary Schools in the Era of PISA and TIMSS (pp. 17-31). Springer International Publishing, 2015.

Laursen H. P. \& Mogensen Dahlstrup, N. (2016). Timespacing competence: multilingual children's linguistic worlds. Social Semiotics, doi: http://dx.doi.org/10.1080/10350330.2015.1137163

Lave, J. \& Wenger, E. (1991). Situated learning: Legitimate peripheral participation. Cambridge: Cambridge University Press.

Luke, A. (2004). On the material consequences of literacy. Language and Education, 18(3), 331-334.

Luke, A. \& Freebody, P. (1999): Further notes on the Four Resources Model. Reading Online. www. readingonline.org/research/lukefreebody.html [collected 2012-08-16].

Mehan, H. (1979). Learning Lessons: Social Organization in the Classroom. Cambridge: Harvard University Press.

National Agency of Education (2011). Curriculum for the compulsory school, preschool class and the recreation centre, Lgr11. 2011. http://www.skolverket.se/om-skolverket/publikationer [collected 2016-05-30].

Ødegaard, M., Arnesen, N. E. \& Klette, K. (2015). Talk and Use of Language in the Science Classroom: Characteristic Features. In K. Klette, O. Bergem \& A. Roe (Eds.), Teaching and Learning in Lower Secondary Schools in the Era of PISA and TIMSS (pp. 101-112). Springer International Publishing, 2015.

Schmidt, Catarina. (2013). Att bli en sån som läser: Barns menings- och identitetsskapande genom texter. rebro: Örebro Studies in Education 33.

Sinclair, J. \& Coulthard, R. (1975). Towards an Analysis of Discourse: The English Used by Teachers and Pupils. Oxford: Oxford University Press.

Skaftun, A. (2015). Leseopplæring og fagenes literacy. Nordic fournal of Literacy Research, Vol. 1, 1-15. http:// dx.doi.org/10.17585/njlr.v1.170

Skoog, Marianne (2012). Skriftspråkande i förskoleklass och årskurs 1. Örebro: Örebro Studies in Education 33.

Street, B. V. (2003). What's "new" in New Literacy Studies? Critical approaches to literacy in theory and practice. Current issues in comparative education, 5(2), 77-91.

Street, B. V. (1993). Cross-cultural Approaches to Literacy. Cambridge: Cambridge University Press.

Säljö, R. (2000). Lärande i praktiken. Ett sociokulturellt perspektiv. Stockholm: Prisma.

Tanner, M. (2014). Lärarens väg genom klassrummet. Lärande och skriftspråkande $i$ bänkinteraktioner på mellanstadiet. Doktorsavhandling. Karlstad University Studies 2014: 27.

Vesteraas Danbolt, A. M. \& Iversen Kulbrandstad, L. (2012). Teacher Reflections under Changing Conditions for Literacy Learning in Multicultural Schools in Oslo. In A. Pitkänen-Huhta \& L. Holm (Eds.), Literacy Practices in Transition. Perspectives from the Nordic Countries (pp. 209-227). Bristol, NY, Ontario: Multilingual.

Vetenskapsrådet (2011). God forskningssed. Vetenskapsrådets rapportserie 1: 2011. www.vr.se (Swedish Research Counsil).

Wahlström, N. (2016). A third wave of European education policy: Transnational and national conceptions of knowledge in Swedish curricula. European Educational Research fournal, 15(3), 298-313.

Vygotsky, L. S. (1978). Mind in Society. Cambridge, MA: Harvard University Press. 